\title{
RIBA PROHIBITION FOR THE COMMUNITY ECONOMIC SUSTAINABILITY
}

\author{
Yanto Ramli, Eko Tama Putra Saratian, Mochamad Soelton, and Margono Setiawan \\ Universitas Mercu Buana Jakarta, Indonesia \\ Universitas Brawijaya, Indonesia.
}

\begin{abstract}
This is a community service related to the development of economic society through socialization on riba and muamalah principle in the daily transaction. Nowadays, some people in Indonesia have begun to care about the dangers of riba and its impact on the economy. Muslims have believed that riba is haram. Some of them certainly can define as well as interpret the term riba. According to the perspective, Islam always encourages the practice of profit sharing and forbids riba. Ironically, there are still many ordinary people do not understand the general rules of riba. In returning the economic and monetary to riba-free system, it is necessary to learn deeply about this subject. For this reason, there is a need for socialization to the wider community to increase good understanding of the riba and get literacy about sharia finance well and certainly can be implemented in family financial planning in Indonesia.
\end{abstract}

Keywords: Economic Sharing, Interest, Muamalah, Riba, Sustainable Finance

\section{INTRODUCTION}

Nowadays, some people in Indonesia have begun to care about the dangers of riba and its impact on the economy. Muslims have believed that riba is haram. Some of them certainly can define as well as interpret the term of riba. The failure of the current economic and monetary system is caused by the riba. According to the perspective, Islam always encourages the practice of profit sharing and forbids riba. Ironically, there are still many ordinary people do not understand the general rules of riba.

Basically, people without knowledge are sentient and ignorant creatures as the word of Allah Subhanahu Wa Ta'ala "Verily, we have revealed the message to the heavens, the earth and the mountains, then all are reluctant to assume that mandate and they are worried that they will betray it, and be endured. that mandate by humans. Indeed, man is very wrong and very ignorant "(Al-Qur'an, Al-Ahzab: 72). Humans have turbulent passions, always feel lacking and never feel satisfied, according to their character and characteristics. Thus, halal transactions are no longer the main goal because they are often associated with minimal profits, a long and difficult process to obtain. This is also in line with the words of the Prophet Shallallahu 'Alaihi Wasallam, from Abu Hurairah Radhiyallahu' Anhu, that he Shallallahu 'Alaihi Wasallam said "there will come a time to mankind, they will no longer care about how to obtain wealth, whether through lawful means. or in an unlawful way "(HR. Bukhari).

Rasulullah Shallallahu "Alaihi Wasallam has also conveyed threats to those who eat illicit wealth. He Shallallahu "Alaihi Wasallam said," actually will not enter the paradise of meat that grows from illicit wealth. Hell is more appropriate for him "(HR Ahmad and Ad-Darimi). Sustenance must come from a halal source and the purpose of use must also be channeled to those who do not violate the Shari'a, as the words of the Prophet Shallallahu 'Alaihi Wasallam "will not shift the footprints of a servant on the Day of Resurrection, until he is asked about four cases, (ie): about: his age for what he spent, about his body for what he used, about his wealth where he got it and where he put it, and about his knowledge, what he had practiced "(HR. At-Tirmidzi and Ad-Darimi). Likewise from Jabir's friend Radhiyallahu 'Anhu, that the Prophet Shallallahu 'Alaihi Wasallam said: "Do not assume that your fortune is slow down. Truly, no one leaves this world, but after his income is complete. Look for fortune in a good way (by) taking the halal and leaving the haram matters "(HR Al-Hakim and Al-Baihaqi).

The family is the smallest organization but has a great impact for all its members, one of which is in the formation of a conscious and wise character in financial management. Currently the government through the Authority also calls on the public to continue to push forward the development of the Sharia Finance Industry which has developed rapidly in the last five years both in terms of the number of actors and sharia financial assets. With this phenomenon, it is felt necessary to disseminate to the public about the dangers of riba and its impact on the economy. 


\section{LITERATURE REVIEW}

According to Chair (2014), riba is an addition to more than the original capital, riba transactions are usually often found in accounts receivable debt transactions where creditors ask for additional capital from the original to the debtor. Riba is often also translated to mean additional money on capital obtained in a way that is prohibited by Shara ', either with a small additional amount or even with a large additional amount. Riba (interest) has become the fad of every conventional financial transaction. This is an idea postulated by the capitalist not minding its implication to the economy in as far as they are accumulating wealth out of it (Mohammad, 2016).

According to Ghofur (2016), the Qur'an itself has explained in detail the stages of the prohibition of riba. The first stage simply describes the negative elements in riba (Al-Qur'an, Ar-Ruum, $30: 39$ ). Then followed by the sign of forbidden riba with the delivery of condemnation of the Jews who practice riba (Al-Qur'an, An-Nisa 4 : 160-161). Next, the Qur'an explicitly forbids riba with the limitation of adh fan mudhā afan (Al-Qur'an, Ali Imron, $3: 130$ ) which is followed by a total prohibition of riba in various forms (Al-Qur'an, Al-Baqarah, $2: 275$ - 276).

Allah Subhanahu Wa Ta'ala shows the prohibition of riba in the Al-Qur'an as follows:

"And something riba (additional) that you give so that he adds to human wealth, then riba does not add to the side of God. And, what you give in the form of zakat that you mean to achieve the pleasure of Allah, then (who do so) are the people who multiply (the reward)" (Al-Qur'an, Ar-Ruum, 30: 39).

"So, because of the tyranny of the Jews, we forbid them from eating good food (which was formerly) lawful for them, and because they prevented many (people) from the path of Allah, and caused them to eat riba, when in fact they were forbidden from him, and because they ate people's wealth in a vanity. We have provided for those who disbelieve among them a painful punishment" (Al-Qur'an, An-Nisa 4: 160-161).

"O you who believe, do not eat riba by multiplying and fear you of Allah so that you will have good fortune. Preserve yourself from the fires of hell, provided for those who disbelieve" (Al-Qur'an, Ali Imron, 3: 130).

"People who eat riba cannot stand, but stand like people who are possessed by devils because of (pressure) insanity. That is because they say that buying and selling is the same as riba. Though Allah has justified the sale and purchase and forbid riba. Anyone who gets a warning from his Lord, then he stops, then what he has obtained first belongs to him and his affairs (it's up to) to God. Whoever repeats, they are the inhabitants of hell, they are eternal in it. Allah destroys riba and fertilizes alms. Allah does not like anyone who remains in disbelief and is wrapped in sin" (Al-Qur'an, Al-Baqarah, 2: 275 - 276).

"O you who believe, fear Allah and leave the rest of riba (that has not been collected) if you are a believer. So, if you don't work (leaving the rest of riba) then know that Allah and His Messenger will fight you. However, if you repent (of riba taking), then for you the subject of your treasure; you are not persecuting nor persecuted" (AlQur'an, Al-Baqarah, 2: 278 - 279).

The prohibitions and threats for usurers in some of the Hadiths are as follows:

From Abdullah bin Hanzhalah, that the Prophet Shallallahu 'Alaihi Wasallam said: "One dirham of riba money consumed by someone in a state of knowing that it is riba money is greater than adultery 36 times" (HR. Ahmad and Ath-Thabrani).

From Ibn Mas'ud, that the Prophet Shallallahu 'Alaihi Wasallam said: "Riba has 73 doors (levels), the lowest (sin) is the same as someone who commits adultery with his mother!" (HR. Al Hakim and Al Baihaqi).

From Jabir, that the Prophet Shallallahu 'Alaihi Wasallam condemned those who received riba, those who paid it, and those who recorded it, and two of their witnesses, then he said, "They are all the same" (HR. Muslim).

From Aun bin Abi Juhaifa, "My father bought a slave whose job was to burn (to get dirty blood from the body), my father then destroyed the slave's cupping equipment. I asked father why he did it. My father replied, that the Prophet Shallallahu 'Alaihi Wasallam forbade receiving money from the transactions of 
blood, dogs, and kasab women slaves, he also cursed the work of tattoo makers and who asked for tattooing, receiving and giving riba and he cursed the makers of drawings" (HR. Bukhari).

It was from Abdurrahman bin Abu Bakr that his father said "Rasulullah Shallallahu 'Alaihi Wasallam prohibits the sale of gold and gold and silver with silver unless it is equal in weight, and allows us to sell gold with silver and vice versa as we wish" (HR. Bukhari).

"That he was blessed by two angels and they said, 'Come with us.' Until finally the two angels took him to a river of blood, in the river there was a person who was swimming. Meanwhile on the banks of the river there was one more person. When the person in the middle of the river wants to pull over, the man on the edge of the river throws his mouth with stones, until he returns to his original place (middle of the river of blood). Then the Prophet Shallallahu 'Alaihi Wasallam said:' I asked the two angels about the person who was in the river. 'They answered,' The person you came to, who swam in the river and then his mouth was gagged with stones, he is a usurious eater" (HR. Bukhari).

\section{METHOD}

In this Community Service, the methods used are interactive lectures, discussion and question and answer. This lecture was packaged as a socialization activity held on March 14th, 2019 at $09.00-12.00$ at the RPTRA Kampung Baru, Jalan Teratai Kampung Baru RT. 009/010, Kelurahan, Kembangan Utara, Kecamatan Kembangan, Jakarta Barat, DKI Jakarta. This activity was attended by around of 50 students from Al-Washilah 1 Jakarta Vocational School.

The purpose of this activity is to provide socialization and counseling to develop products and improve the Islamic financial portfolio in North Kembangan, Kembangan, West Jakarta. The objectives of this activity include: (a) increasing public understanding of the principles of muamalah and the sharia economic system, (b) understanding the prohibitions and negative impacts of riba on the economy, (c) providing an introduction to Islamic financial instruments as a solution in managing family finances.

\section{RESULT AND DISCUSSION}

Riba is considered by many as a trigger for the crisis. The main pillars of riba which are considered as the main causes of the crisis include; interest, fiat money and fractional reserve requirements in the banking system. These three pillars complement each other in creating money creation so that it increases money circulation without backing up gold or other real assets, which consequently causes inflation, damages the economy and the monetary system. Riba is the source of the problem of all problems. The majority of poverty occurs not because of the unavailability of jobs or low levels of education, far from that this is due to damage to the system resulting from the pillars of riba. The excessive exploitation of natural resources is also caused by the riba system, thus forcing developing countries to pay principal and interest loans with their natural resources. Riba also causes excessive human exploitation. They have to go the extra mile to pay debts, which in essence will never be paid off at a macro level, because the majority of new money is created by channeling credit in the banking system.

So do not be surprised if Allah Subhanahu Wa Ta'ala threatens the perpetrators of riba with such a heavy threat and a great sin, as he said:

"O you who believe, fear Allah and leave the rest of riba (that has not been collected) if you are a believer. So, if you don't work (leaving the rest of riba) then know that Allah and His Messenger will fight you. However, if you repent (of riba taking), then for you the subject of your treasure; you do not persecute nor are you persecuted" (Al-Qur'an, Al-Baqarah, 2: 278 - 279).

Furthermore, the Prophet Muhammad Shallallahu 'Alaihi Wasallam conveyed a threat to the perpetrators of riba in the following Hadiths:

From Abdullah bin Hanzhalah, that the Prophet Shallallahu 'Alaihi Wasallam said: "One dirham of riba money consumed by someone in a state of knowing that it is riba money is greater than adultery 36 times" (HR. Ahmad and Ath-Thabrani).

From Ibn Mas'ud, that the Prophet Shallallahu 'Alaihi Wasallam said: "Riba has 73 doors (levels), the lowest (sin) is the same as someone who commits adultery with his mother!" (HR. Al Hakim and Al Baihaqi). 
From Aun bin Abi Juhaifa, "My father bought a slave whose job was to burn (to get dirty blood from the body), my father then destroyed the slave's cupping equipment. I asked father why he did it. My father replied, that the Prophet Shallallahu 'Alaihi Wasallam forbade receiving money from the transactions of blood, dogs, and kasab women slaves, he also cursed the work of tattoo makers and who asked for tattooing, receiving and giving riba and he cursed the makers of drawings" (HR. Bukhari).

"That he was blessed by two angels and they said, 'Come with us.' Until finally the two angels took him to a river of blood, in the river there was a person who was swimming. Meanwhile on the banks of the river there was one more person. When the person in the middle of the river wants to pull over, the man on the edge of the river throws his mouth with stones, until he returns to his original place (middle of the river of blood). Then the Prophet Shallallahu 'Alaihi Wasallam said:' I asked the two angels about the person who was in the river. 'They answered,' The person you came to, who swam in the river and then his mouth was gagged with stones, he is a usurious eater" (HR. Bukhari).

\section{CONCLUSION}

From the discussion above, some conclusions can be drawn that based on the verses of the Qur'an, the scholars agree that riba is something that is prohibited because it is considered very clear and chronologically the essence of the prohibition can be understood. On the other hand the Koran strongly encourages people to give alms, as his words in the Koran, Al-Baqarah, verse 276 "Allah destroy riba and fertilize alms".

Based on the discussion in the previous chapters, it can be concluded that this socialization is expected to increase public knowledge, including: (a) the realization of an increase in public understanding of the Muamalah Principles and Sharia Economic System, (b) the realization of an understanding of the prohibition and the negative impact of riba on the economy, (c) introduction and additional sharia financial literacy as a solution in family financial planning.

In addition, Prophet Muhammad Shallallaahu 'Alaihi Wasallam said: "Whoever sees (whatever is) munkar, then change it with his hands; and if he is unable to do so, then with his tongue; and if he is unable to do so, then with his heart; and that is the weakest faith" (HR. Muslim).

\section{REFERENCES}

Al-Qur'an, Al-Karim.

Chair, Wasilul. (2014). Riba dalam Perspektif Islam dan Sejarah. Jurnal Iqtishadia. Vol. 1, No. 1 Edisi 1 98-113.

Ghofur, Abdul. (2016). Konsep Riba dalam Al-Qur'an. Jurnal Economica. Vol. VII, Edisi 1 1-26.

Hadits Bukhari, Muslim, Ahmad, Ad-Darimi, At-Tirmidzi, At-Thabrani, Al-Hakim, Al-Baihaqi.

Mohammad, Ibrahim. (2016). Riba (Usury); a Tool that should be Carved out of Financial Transactions. Turkish Journal of Islamic Economics. Vol. 3, No. 2, 13-24.

Soelton, Mochamad, Nugrahati, Tati, (2018). How Complaining Behaviors Effect on Coping Stress and Anxiety?. International Journal of Saudi Journal of Business and Management Studies (SJBMS). Vol. 3, No. 6. 623-628.

Soelton et al, (2019). Gender: Stress Levels on Performance in Modern Industry. International Journal Archives of Business Research (United Kingdom). Vol. 7, No 2, 72-81

Soelton et al, (2018). Toward The Best Strategy In Minimizing The Spread of Drug Users. International Conference on Community Development in Asia. Vol 1. No 1, 171-176 